\title{
A Study of the Role of Nigella Sativa Oil in the Eradication of H.Pylori Infection in Symptomatic Children
}

\author{
NOHA S.A. HAMED ESMAIL, M.Sc.*; RASHA M.G. EL-SHAFIEY, M.D.*; \\ AHMAD M. NAIEM ABD ELAL, M.D.** and AMAL S. ELBENDARY, M.D.* \\ The Departments of Pediatrics* and Clinical Pathology**, Faculty of Medicine, Tanta University
}

\begin{abstract}
Background: Helicobacter pylori (H.pylori) is a gramnegative flagellated spiral bacterium which is usually acquired during childhood, and the infection persists throughout life unless specifically treated. Resistance against H.pylori is increasing, and it is necessary to find new effective agents. Nigella sativa has possible role of N. sativa oil in eradication of H.pylori infection in symptomatic children.
\end{abstract}

Aim of Study: The aim as present work was to study the possible role of N.sativa oil in eradication of H.pylori infection in symptomatic children.

Subjects and Methods: This randomized clinical trial was carried out on 60 symptomatic children with being proven positive for H.pylori stool antigen test from those attending the Diarrheal Diseases and Nutrition Unit of Pediatric Department at Tanta University. The patients were randomly assigned to one of the following three groups: Group 1: Included 20 patients who received triple therapy for two weeks including clarithromycin $15 \mathrm{mg} / \mathrm{kg} /$ day divided into two doses + metrinodazole $15-20 \mathrm{mg} / \mathrm{kg} /$ day divided into two doses + omeprazole $1 \mathrm{mg} / \mathrm{kg} /$ day, for two weeks. Group 2: Included 20 patients who received $2 \mathrm{~g}$ Nigella sativa oil two capsules (each of $450 \mathrm{mg}$ ) twice daily after meals and omeprazole $1 \mathrm{mg} / \mathrm{kg} /$ day for two weeks. Group 3: Included 20 patients who received triple therapy combined with Nigella sativa oil for two weeks. All patients had a full sheet, complete clinical examination and routine laboratory investigations (CBC, ALT, AST, BUN, S.creatinine, ESR), occult blood in stool, H.pylori antigen in stool before and after treatment and assessment of severity of dyspepsia using "Modified Glasgow Dyspepsia Severity Score" before and after treatment.

Results: There was statistically significant differences between the three studied groups as regard H.pylori antigen in stool after treatment. The difference was evident on comparing either Group I or Group III versus Group II. Significantly more cases in Group I (65\%) and in Group III (75\%) became negative to H.pylori antigen in stool in comparison to only $(30 \%)$ of the patients in Group II.

Conclusion: Addition of N.sativa to the traditional triple therapy increased the probability of H.pylori eradication more than that achieved through triple therapy alone.

Correspondence to: Dr. Noha S.A. Hamed Esmail, The Department of Pediatric, Faculty of Medicine, Tanta University
Key Words: Helicobacter pylori - Triple therapy - Nigella sativa-Dyspepsi.

\section{Introduction}

HELICOBACTER pylori (H.pylori) is a gramnegative flagellated spiral bacterium which is usually acquired during childhood, and the infection persists throughout life unless specifically treated [1]. The possible routes of infection are feco oral, oro oral and gastro oral [2].

The prevalence of H.pylori infection among children is diverse and dependent on many factors. Lower prevalence rates are reported in communities with higher socioeconomic status and generally better environmental conditions, while the highest percentage of infected children is observed in developing countries [3]. Prevalence of H.pylori infection in Egyptian children at age of 5-15 years is about $50 \%$ [4] .

Generally, only a small proportion of H.pylori infected children develop symptoms which are non specific and may include epigastric pain especially after meals, night-time waking, unexplained nausea and/or vomiting, anorexia, hematemesis, and irondeficiency anemia $[\mathbf{5}]$.

The relationship of H.pylori infection with growth retardation in children is controversial. However, in poor resource settings where malnutrition, parasitic/enteropathogen, and H.pylori infection coexist in young children, H.pylori might play a potential role [6].

H.pylori is the causative agent of chronic gastritis and peptic ulcer diseases and is an important risk factor for the development of gastric cancer and Mucosal-Associated Lymphoid Tissue (MALT) lymphoma [7]. 
Diagnosis of H.pylori may be through invasive or non invasive techniques. Invasive tests include an Upper Gastrointestinal Endoscopy (UGIE) and biopsy for detection of organism itself or catalase reaction. Non invasive tests include serology, detection of H.pylori antibodies in urine and saliva, Urea Breath Test (UBT), and stool antigen test [8]

Stool antigen test is an excellent tool in diagnosing H.pylori infection and confirming eradication in children after treatment through detecting bacterial antigen in stools using monoclonal antibodies [8]

Triple therapy including clarithromycin with metronidazole and proton pump inhibitors is the standard therapy for H.pylori eradication as H.pylori has a peculiar habitat and characteristics, it is difficult to eradicate with a single antibiotic oral amoxicillin may replace one of the two anti microbials in the triple therapy [9] .

Studies revealed that H.pylori has been found to be resistant to one or more of the antimicrobial drugs of the triple therapy [10]. The rising prevalence of H.pylori antibiotic resistance emphasizes the need for discovery of new and safe modalities for treatment of H.pylori infection and the resulting gastroduodenal disease. It has been shown that essential oils extracted from plants like Nigella sativa oil are bactericidal against H.pylori without the development of acquired resistance, suggesting that essential oils may have potential benefit as new and safe agents for inclusion in anti-H.pylori regimens [11]

A study was conducted in Saudi Arabia using Nigella sativa oil with proton pump inhibitors to treat H.pylori adult with non ulcer dyspeptic symptoms. The results were encouraging [12]

\section{Subjects and Methods}

This randomized clinical trial was carried out on 60 symptomatic children proven positive for H.pylori stool antigen test from those attending the Diarrheal Diseases and Nutrition Unit of Pediatric Department at Tanta University Hospital in the period between June/2017 to May/2018. The patients were randomly assigned to one of the following three groups:

- Group 1: Included 20 patients who received triple therapy for two weeks including clarithromycin $15 \mathrm{mg} / \mathrm{kg} /$ day divided into two doses + metrinodazole $15-20 \mathrm{mg} / \mathrm{kg} /$ day divided into two doses + omeprazole $1 \mathrm{mg} / \mathrm{kg} /$ day, for two weeks.

- Group 2: Included 20 patients who received $2 \mathrm{~g}$ Nigella sativa oil two capsules (each of $450 \mathrm{mg}$ ) twice daily after meals and omeprazole $1 \mathrm{mg} / \mathrm{kg} /$ day for two weeks.

- Group 3: Included 20 patients who received triple therapy combined with Nigella sativa oil for two weeks.

\section{All children in this study were subjected to:}

A- Complete history taking with special emphasis on: Character of abdominal pain, other dyspeptic symptoms, relation with fever, vomiting, weight loss, alleviating and precipitating factors e.g. meals, stress, sleep, history of nongastrointestinal symptoms as headache, migraine, sweating, pallor, dizziness, family history of gastrointestinal disorders, school problems, death and divorce.

B- Assessment of severity of dyspepsia using "Modified Glasgow Dyspepsia Severity Score".

\begin{tabular}{|c|c|c|}
\hline $\begin{array}{l}\text { - Intensity of } \\
\text { pain }\end{array}$ & $\begin{array}{l}\text { - Mild } \\
\text { - Moderate } \\
\text { - Severe }\end{array}$ & $\begin{array}{l}1 \\
2 \\
3\end{array}$ \\
\hline $\begin{array}{l}\text { - Duration of } \\
\text { pain }\end{array}$ & $\begin{array}{l}\cdot<15 \mathrm{~s} \\
\cdot 15-60 \mathrm{~s} \\
\cdot>60 \mathrm{~s}\end{array}$ & $\begin{array}{l}1 \\
2 \\
3\end{array}$ \\
\hline $\begin{array}{l}\text { - Incidence of } \\
\text { pain }\end{array}$ & $\begin{array}{l}\text { - Once every } 10 \text { days } \\
\text {-2-5 times weekly } \\
\text { - Every day }\end{array}$ & $\begin{array}{l}1 \\
2 \\
3\end{array}$ \\
\hline $\begin{array}{l}\text { • Nocturnal } \\
\text { awakeness }\end{array}$ & $\begin{array}{l}\text { - Never } \\
\text { - Rarely (at least two times for the last three } \\
\text { months) } \\
\text { - Usually }\end{array}$ & $\begin{array}{l}0 \\
1\end{array}$ \\
\hline - Absenteeism & $\begin{array}{l}\text { - Less than one day every week } \\
\text { - One day every week } \\
\text { - Everyday }\end{array}$ & $\begin{array}{l}1 \\
2 \\
3\end{array}$ \\
\hline - Vomiting & $\begin{array}{l}\text { - Never } \\
\text { - Rarely (2-4 times during the last three } \\
\text { months) } \\
\text { - Usually }\end{array}$ & $\begin{array}{l}0 \\
1\end{array}$ \\
\hline
\end{tabular}

According to this scale we divided patients with dyspepsia into three groups: Mild (score $<6$ ), moderate (score 7-10) and severe (score $>11$ ) [13]

C- Clinical examination.

D- Investigations including: Complete blood count, blood urea nitrogen and serum creatinine, Aspartate aminotransferase (AST) and alanine aminotransferase (ALT), Erythrocyte Sedimentation Rate (ESR), occult blood in stool, H.pylori antigen in stool after treatment using ELISA.

E- Reassessment of severity of dyspepsia using "Modified Glasgow Dyspepsia Severity Score" after treatment. 


\section{Results}

Table (1) showed the distribution of demographic data in studied groups. There was no statistically significant differences between the three groups.

Table (2) showed symptoms in studied groups. There was no statistically differences between the three groups. The most common presenting symptoms in the studied patients were abdominal pain (83.33\%) and vomiting (63.33). Precipitating factors including meals, stress and sleep were evident in $71.67 \%$ of studied patients.

Table (3) showed history of non-gastrointestinal symptoms in the studied groups. There was no statistically significant differences between the three groups as regard positive history of headache, migraine, sweating, pallor and dizziness. Positive history for pallor and headache were found in $53.33 \%$ and $45 \%$ of patients respectively.

Table (4) showed the family history in the studied groups. There was no statistically significant differences between the three studied groups as regard positive family history of gastrointestinal disorders, school problems, death and divorce.

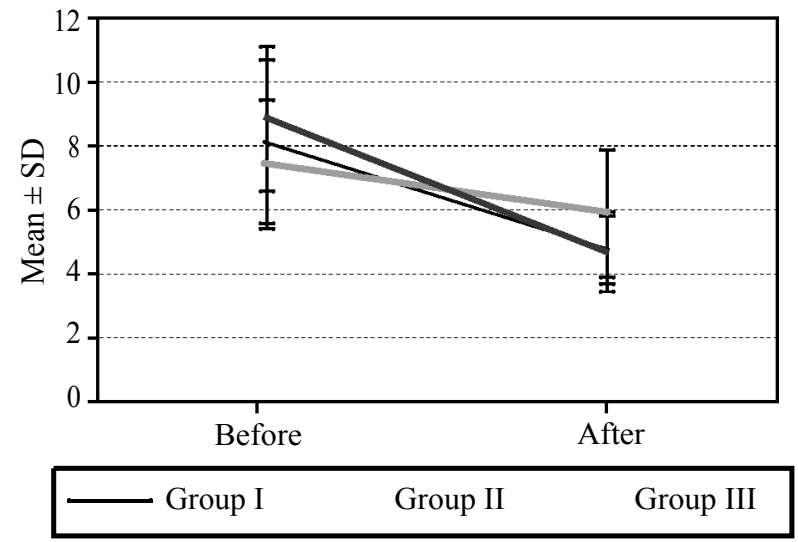

Fig. (1): The modified Glasgow dyspepsia score in the studied groups before and after treatment.
Table (5) and Fig. (1) showed modified Glasgow dyspepsia score in the studied groups before and after treatment. Within the same group, modified Glasgow dyspepsia score showed significant improvement in each of the studied groups on comparing values before and after treatment. On comparing studied groups, there was no significant differences between the mean score values in the three studied groups before treatment; while after treatment, significant differences were found on comparing either Group I or Group III versus Group II. The mean score value was significantly lower in Group III compared to both Groups I and II.

Table (6) and Fig. (2) showed the result of H.pylori antigen in stool in studied groups after treatment. There was statistically significant differences between the three studied groups. The difference was evident on comparing either Group I or Group III versus Group II. Significantly more cases in Group I (65\%) and in Group III (75\%) became negative to H.pylori antigen in stool in comparison to only $(30 \%)$ of the patients in Group II.

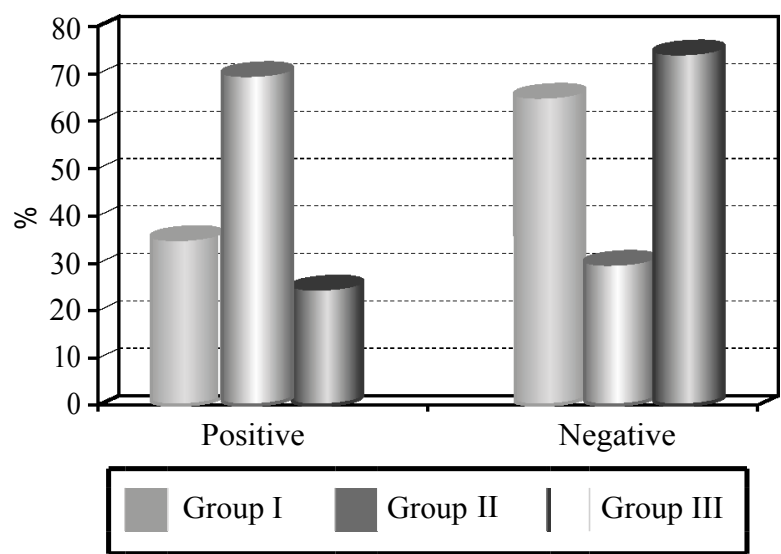

Fig. (2): H.pylori antigen in stool after treatment in the studied groups.

Table (1): Demographic data of studied groups.

\begin{tabular}{|c|c|c|c|c|c|c|c|c|}
\hline & \multicolumn{6}{|c|}{ Groups } & \multicolumn{2}{|c|}{$\begin{array}{l}\text { ANOVA or } \\
\text { Chi-Square }\end{array}$} \\
\hline & \multicolumn{2}{|c|}{$\begin{array}{l}\text { Group I } \\
(\mathrm{n}=20)\end{array}$} & \multicolumn{2}{|c|}{$\begin{array}{l}\text { Group II } \\
(\mathrm{n}=20)\end{array}$} & \multicolumn{2}{|c|}{$\begin{array}{c}\text { Group III } \\
(\mathrm{n}=20)\end{array}$} & $\begin{array}{l}\text { F or } \\
\chi^{2}\end{array}$ & $\begin{array}{c}p \text { - } \\
\text { value }\end{array}$ \\
\hline \multicolumn{9}{|l|}{ Age: } \\
\hline Range & \multirow{2}{*}{\multicolumn{2}{|c|}{$\begin{array}{c}6-16 \\
10.600 \pm 3.235\end{array}$}} & \multirow{2}{*}{\multicolumn{2}{|c|}{$\begin{array}{c}6-14 \\
9.500 \pm 2.6\end{array}$}} & \multirow{2}{*}{\multicolumn{2}{|c|}{$\begin{array}{c}6-16 \\
11.250 \pm 2.900\end{array}$}} & 1.830 & 0.170 \\
\hline Mean \pm SD & & & & & & & & \\
\hline \multicolumn{9}{|l|}{ Sex: } \\
\hline Male & 8 & 40.00 & 7 & 35.00 & 7 & 35.00 & 0.144 & 0.931 \\
\hline Female & 12 & 60.00 & 13 & 65.00 & 13 & 65.00 & & \\
\hline \multicolumn{9}{|l|}{ Community: } \\
\hline Urban & 6 & 30.00 & 5 & 25.00 & 9 & 45.00 & 1.950 & 0.377 \\
\hline Rural & 14 & 70.00 & 15 & 75.00 & 11 & 55.00 & & \\
\hline
\end{tabular}


Table (2): Symptoms in studied groups.

\begin{tabular}{|c|c|c|c|c|c|c|c|c|c|c|}
\hline & \multicolumn{8}{|c|}{ Groups } & \multirow{2}{*}{\multicolumn{2}{|c|}{$\begin{array}{l}\text { Chi- } \\
\text { Square }\end{array}$}} \\
\hline & \multicolumn{2}{|c|}{$\begin{array}{l}\text { Group I } \\
(\mathrm{n}=20)\end{array}$} & \multicolumn{2}{|c|}{$\begin{array}{c}\text { Group II } \\
(\mathrm{n}=20)\end{array}$} & \multicolumn{2}{|c|}{$\begin{array}{c}\text { Group III } \\
(\mathrm{n}=20)\end{array}$} & \multicolumn{2}{|c|}{ Total } & & \\
\hline & $\mathrm{N}$ & $\%$ & $\mathrm{~N}$ & $\%$ & $\mathrm{~N}$ & $\%$ & $\mathrm{~N}$ & $\%$ & $x^{2}$ & $p$-value \\
\hline \multicolumn{11}{|c|}{ Abdominal pain: } \\
\hline Positive & 17 & 85.00 & 17 & 85.00 & 16 & 80.00 & 50 & 83.33 & 0.240 & 0.887 \\
\hline Negative & 3 & 15.00 & 3 & 15.00 & 4 & 20.00 & 10 & 16.67 & & \\
\hline \multicolumn{11}{|l|}{ Fever: } \\
\hline Positive & 3 & 15.00 & 0 & 0.00 & 4 & 20.00 & 7 & 11.67 & 4.205 & 0.122 \\
\hline Negative & 17 & 85.00 & 20 & 100.00 & 16 & 80.00 & 53 & 88.33 & & \\
\hline \multicolumn{11}{|l|}{ Vomiting: } \\
\hline Positive & 14 & 70.00 & 10 & 50.00 & 14 & 70.00 & 38 & 63.33 & 2.297 & 0.317 \\
\hline Negative & 6 & 30.00 & 10 & 50.00 & 6 & 30.00 & 22 & 36.67 & & \\
\hline \multicolumn{11}{|l|}{ Wt loss: } \\
\hline Positive & 5 & 25.00 & 4 & 20.00 & 5 & 25.00 & 14 & 23.33 & 0.186 & 0.911 \\
\hline Negative & 15 & 75.00 & 16 & 80.00 & 15 & 75.00 & 46 & 76.67 & & \\
\hline \multicolumn{11}{|c|}{ Priciptating factor: } \\
\hline Positive & 15 & 75.00 & 15 & 75.00 & 13 & 65.00 & 43 & 71.67 & 0.657 & 0.720 \\
\hline Negative & 5 & 25.00 & 5 & 25.00 & 7 & 35.00 & 17 & 28.33 & & \\
\hline
\end{tabular}

Table (3): History of non-gastrointestinal symptoms in studied groups.

\begin{tabular}{|c|c|c|c|c|c|c|c|c|c|c|}
\hline & \multicolumn{8}{|c|}{ Groups } & \multirow{2}{*}{\multicolumn{2}{|c|}{$\begin{array}{l}\text { Chi- } \\
\text { Square }\end{array}$}} \\
\hline & \multicolumn{2}{|c|}{$\begin{array}{l}\text { Group I } \\
(\mathrm{n}=20)\end{array}$} & \multicolumn{2}{|c|}{$\begin{array}{c}\text { Group II } \\
(\mathrm{n}=20)\end{array}$} & \multicolumn{2}{|c|}{$\begin{array}{c}\text { Group III } \\
(\mathrm{n}=20)\end{array}$} & \multicolumn{2}{|c|}{ Total } & & \\
\hline & $\mathrm{N}$ & $\%$ & $\mathrm{~N}$ & $\%$ & $\mathrm{~N}$ & $\%$ & $\mathrm{~N}$ & $\%$ & $x^{2}$ & $p$-value \\
\hline \multicolumn{11}{|l|}{ Headache*: } \\
\hline Positive & 9 & 45.00 & 10 & 50.00 & 8 & 40.00 & 27 & 45.00 & 0.404 & 0.817 \\
\hline Negative & 11 & 55.00 & 10 & 50.00 & 12 & 60.00 & 33 & 55.00 & & \\
\hline \multicolumn{11}{|l|}{ Migraine: } \\
\hline Positive & 3 & 15.00 & 3 & 15.00 & 2 & 10.00 & 8 & 13.33 & 0.288 & 0.866 \\
\hline Negative & 17 & 85.00 & 17 & 85.00 & 18 & 90.00 & 52 & 86.67 & & \\
\hline \multicolumn{11}{|l|}{ Sweating: } \\
\hline Positive & 7 & 35.00 & 6 & 30.00 & 3 & 15.00 & 16 & 26.67 & 2.216 & 0.330 \\
\hline Negative & 13 & 65.00 & 14 & 70.00 & 17 & 85.00 & 44 & 73.33 & & \\
\hline \multicolumn{11}{|l|}{ Pallor*: } \\
\hline Positive & 12 & 60.00 & 12 & 60.00 & 8 & 40.00 & 32 & 53.33 & 2.143 & 0.343 \\
\hline Negative & 8 & 40.00 & 8 & 40.00 & 12 & 60.00 & 28 & 46.67 & & \\
\hline \multicolumn{11}{|l|}{ Dizziness: } \\
\hline Positive & 4 & 20.00 & 3 & 15.00 & 3 & 15.00 & 10 & 16.67 & 0.240 & 0.887 \\
\hline Negative & 16 & 80.00 & 17 & 85.00 & 17 & 85.00 & 50 & 83.33 & & \\
\hline
\end{tabular}


Table (4): Family history in the studied groups.

\begin{tabular}{|c|c|c|c|c|c|c|c|c|c|c|}
\hline & \multicolumn{8}{|c|}{ Groups } & \multirow{2}{*}{\multicolumn{2}{|c|}{$\begin{array}{l}\text { Chi- } \\
\text { Square }\end{array}$}} \\
\hline & \multicolumn{2}{|c|}{$\begin{array}{l}\text { Group I } \\
(n=20)\end{array}$} & \multicolumn{2}{|c|}{$\begin{array}{c}\text { Group II } \\
(n=20)\end{array}$} & \multicolumn{2}{|c|}{$\begin{array}{c}\text { Group III } \\
(\mathrm{n}=20)\end{array}$} & \multicolumn{2}{|c|}{ Total } & & \\
\hline & $\mathrm{N}$ & $\%$ & $\mathrm{~N}$ & $\%$ & $\mathrm{~N}$ & $\%$ & $\mathrm{~N}$ & $\%$ & $x^{2}$ & $p$-value \\
\hline \multicolumn{11}{|c|}{$\begin{array}{l}\text { Gastrointestinal } \\
\text { disorder: }\end{array}$} \\
\hline Positive & 3 & 15.00 & 4 & 20.00 & 3 & 15.00 & 10 & 16.67 & 0.240 & 0.887 \\
\hline Negative & 17 & 85.00 & 16 & 80.00 & 17 & 85.00 & 50 & 83.33 & & \\
\hline \multicolumn{11}{|c|}{ School problems: } \\
\hline Positive & 6 & 30.00 & 5 & 25.00 & 8 & 40.00 & 19 & 31.67 & 1.078 & 0.583 \\
\hline Negative & 14 & 70.00 & 15 & 75.00 & 12 & 60.00 & 41 & 68.33 & & \\
\hline \multicolumn{11}{|l|}{ Death: } \\
\hline Positive & 7 & 35.00 & 6 & 30.00 & 6 & 30.00 & 19 & 31.67 & 0.154 & 0.926 \\
\hline Negative & 13 & 65.00 & 14 & 70.00 & 14 & 70.00 & 41 & 68.33 & & \\
\hline \multicolumn{11}{|l|}{ Divorce: } \\
\hline Positive & 3 & 15.00 & 3 & 15.00 & 2 & 10.00 & 8 & 13.33 & 0.288 & 0.866 \\
\hline Negative & 17 & 85.00 & 17 & 85.00 & 18 & 90.00 & 52 & 86.67 & & \\
\hline
\end{tabular}

Table (5): The modified Glasgow dyspepsia score in the studied groups before and after treatment.

\begin{tabular}{|c|c|c|c|c|c|}
\hline \multirow{2}{*}{$\begin{array}{l}\text { Modified Glasgow } \\
\text { dyspepsia score }\end{array}$} & \multicolumn{3}{|c|}{ Groups } & \multicolumn{2}{|c|}{ ANOVA } \\
\hline & $\begin{array}{l}\text { Group I } \\
(\mathrm{n}=20)\end{array}$ & $\begin{array}{l}\text { Group II } \\
(\mathrm{n}=20)\end{array}$ & $\begin{array}{l}\text { Group III } \\
(\mathrm{n}=20)\end{array}$ & $\mathrm{F}$ & $\begin{array}{c}p- \\
\text { value }\end{array}$ \\
\hline \multicolumn{6}{|l|}{ Before: } \\
\hline Range & $4-14$ & $4-11$ & $6-14$ & 1.849 & 0.167 \\
\hline Mean \pm SD & $8.150 \pm 2.560$ & $7.450 \pm 2.038$ & $8.850 \pm 2.277$ & & \\
\hline \multicolumn{6}{|l|}{ After: } \\
\hline Range & $4-7$ & $4-9$ & $4-9$ & 4.112 & $p=0.021 *$ \\
\hline Mean \pm SD & $4.750 \pm 1.070$ & $5.900 \pm 1.971$ & $4.700 \pm 1.302$ & & $p_{1}=0.047 *$ \\
\hline Paired differences & $3.400 \pm 1.789$ & $1.550 \pm 0.945$ & $4.150 \pm 1.899$ & & $\begin{array}{l}p_{2}=0.994 \\
p_{3}=0.037 *\end{array}$ \\
\hline Paired samples test & $<0.001 *$ & $<0.001 *$ & $<0.001 *$ & & \\
\hline
\end{tabular}

$p=$ Group I vs. Group II vs. Group III. $\quad p 2=$ Group I vs. Group III.

$p 1=$ Group I vs. Group II. $\quad p 3=$ Group II vs. Group III.

Post hoc test $=$ Tukey test.

Table (6): H.pylori antigen in stool after treatment in studied groups.

\begin{tabular}{|c|c|c|c|c|c|c|c|c|c|c|}
\hline \multirow{3}{*}{$\begin{array}{l}\text { H. pylori } \\
\text { antigen in } \\
\text { stool after }\end{array}$} & \multicolumn{8}{|c|}{ Groups } & \multirow{2}{*}{\multicolumn{2}{|c|}{$\begin{array}{l}\text { Chi- } \\
\text { Square }\end{array}$}} \\
\hline & \multicolumn{2}{|c|}{$\begin{array}{l}\text { Group I } \\
(\mathrm{n}=20)\end{array}$} & \multicolumn{2}{|c|}{$\begin{array}{c}\text { Group II } \\
(\mathrm{n}=20)\end{array}$} & \multicolumn{2}{|c|}{$\begin{array}{c}\text { Group III } \\
(\mathrm{n}=20)\end{array}$} & \multicolumn{2}{|c|}{ Total } & & \\
\hline & $\mathrm{N}$ & $\%$ & $\mathrm{~N}$ & $\%$ & $\mathrm{~N}$ & $\%$ & $\mathrm{~N}$ & $\%$ & $x^{2}$ & $p$-value \\
\hline Positive & 7 & 35.00 & 14 & 70.00 & 5 & 25.00 & 26 & 43.33 & 9.095 & $0.011 *$ \\
\hline Negative & 13 & 65.00 & 6 & 30.00 & 15 & 75.00 & 34 & 56.67 & & \\
\hline \multirow[t]{3}{*}{ Total } & 20 & 100.00 & 20 & 100.00 & 20 & 100.00 & 60 & 100.00 & & \\
\hline & \multicolumn{2}{|c|}{ I \& II } & \multicolumn{4}{|c|}{ I \& III } & \multicolumn{4}{|c|}{ II \& III } \\
\hline & \multicolumn{2}{|c|}{$0.027 *$} & \multicolumn{4}{|c|}{0.490} & \multicolumn{4}{|c|}{$0.004 *$} \\
\hline
\end{tabular}




\section{Discussion}

Successful treatment of H.pylori infection with antimicrobial agents can lead to regression of H.pylori-associated disorders. The main reasons for treatment failure are antimicrobial resistance, patient non-adherence and the complexity of the therapy, so it is necessary to find new effective agents [14].

Natural compounds have found their applications in the treatment of refractory diseases. Because of their satisfactory clinical efficacy and low toxicity, N.sativa is one of the oldest documented herbal medicinal plants and has been used for centuries in traditional Arabic medicine [15].

The aim of this study to evaluate the possible role of N.sativa oil in eradication of H.pylori infection in symptomatic children.

This study was conducted on 60 children having complains of dyspeptic symptoms and had positive result for H.pylori infection with age ranged between 5-15 years.

In our study, the (mean \pm SD) age of the enrolled children was 9.5-11.2 \pm 2.9 years in the three studied groups. This agreed with Hasosah et al., 2015 who studied prevalence of H.pylori infection in children where H.pylori infection was more evident (57.7\%) in the 10 year age group while in the study by Abu Zekry, 2013 who studied frequency of H.pylori infection among Egyptian children presenting with gastrointestinal manifestations the mean age was was $7.37 \pm 3.0$ years.

Age was identified as one of the most important risk factors for H.pylori acquisition. Early childhood is the age of acquisition of $\mathrm{H}$. pylori infection in developing countries, whereas in developed countries, infection is acquired after the age of 10 years [16]

As regard gender in our study, $22(36.66 \%)$ were males and $38(63.33 \%)$ were females with male $(\mathrm{m})$ :female (f) ratio $1: 1.7$. This is agreed with Hasosah et al., 2015 which study included 149 males $49.2 \%$ for males and 154 (50.8) for females with $\mathrm{m}:$ f ratio about 1:1. While in Abu-Zekry, 2013 study $81(54 \%)$ of the patients were boys and 69 (46\%) were girls with $\mathrm{m}$ :f 1.17:1.

According to residence in our study, 40 (66.66\%) children came from rural areas and 20 (33.33\%) children came from urban areas. In agreement with our study, Hanafi, 2013 study conducted to determine the seroprevalence of H.pylori in asymptomatic healthy individuals and the possible relationship between H.pylori infection and socio demographic, lifestyle, and environmental factors, he found that H.pylori seropositivity was significantly more frequently encountered among individuals who came rural areas (55.4\%) than among urban residents $(44.6 \%)$. In contrast to Ghasemi Kebria, 2013 study in which $106(54.6 \%)$ children were comed from urban areas and $88(45.4 \%)$ were from rural areas.

In the present study, it was observed that the common presenting symptoms was abdominal pain. In our study 50 children $(83.33 \%$ ) had abdominal pain this agreed with both Correa Silva, 2016 study and Abu-Zekry, 2013 study who reported that $(86 \%)$ and $(82 \%)$ of children infected with H.pylori had abdominal pain respectively. While in Hasosah et al., 2015 study abdominal pain was found in $(57.28 \%)$ children.

The second main presenting symptoms in our study was vomiting in 38 (63.33\%) of studied children. This is in agreement with Raj, 2017 who studied the efficacy of H.pylori serology test in screening symptomatic children, vomiting percentage in H.pylori infected patient was $46 \%$. Also Hasosah et al., 2015 reported that 32 (41.56\%) children who are positive for H.pylori had vomiting.

In our study also, 14 (23.33\%) children had weight loss. This agreed with Raj, 2017 study in which $17 \%$ of H.pylori infected children had weight loss.

In the present study $43(71.67 \%)$ children had priciptating factors for dyspepsia as meals, stress and sleep. Similar findings were reported by Spiroglou et al., 2004 who studied the frequency, clinical manifestations and treatment of functional dyspepsia in childhood, in which 107 (30.74\%) children had priciptating factors.

Also in our study it was found that 27 (45\%) children had headache and this did not agree with Spiroglou et al., 2004 study in which 41 (11.78\%) had headache.

In the present study, 8 (13.33\%) children had migraine this did not agree with Spiroglou et al., 2004 study in which $4(.86 \%)$ had migraine.

In our study, 16 (26.67\%) children had sweating and $32(53.33 \%)$ children had pallor. This did not agree with Spiroglou et al., 2004 study in which $22(6.32 \%)$ and $15(4.31 \%)$ children had sweating and pallor respectively.

Regarding family history in our study, it was observed that $10(16.67 \%)$ children had positive family of gastrointestinal disorders. This simulated 
Wauters, 2017 study in which $28 \%$ of children had positive family history of gastrointestinal disorders and Çınar, 2015 who studied prevalence of H.pylori infection in school and pre-school aged children with $\mathrm{C}-14$ urea breath test and the association with familial and environmental factors, in which $(12.9 \%)$ children had positive family history of gastro intestinal diseases. In our study $6(10 \%)$ children had positive family history of H.pylori infection while Hasosah et al., 2015 reported that $38 \%$ of children had positive family history of H.pylori.

H.pylori infection occurs essentially in childhood, mostly in the family, the mother being the main source [23]. Mother-to-child transmission was strongly suggested in a study of DNA analysis of the H.pylori strains. The data showed identical H.pylori strains between mothers and their toddleraged children. Moreover, the mother who had nausea and vomiting and the use of pacifier for her child were significantly associated with the risk of H.pylori infection in children [24]

Psychological stress and negative life events e.g. school problems, death and divorce has long been recognized as a risk factor for the development of dyspepsia in children. Therefor a particular attention was given to this part of the history in our study [25] .

In the present study 19 (31.67\%) children had history of school problems, 19 (31.67) had positive family history of death and $8(13.33 \%)$ had positive family divorce.

In our study as regard total modified glasgow dyspepsia severity score, within the same group, it showed significant improvement in each of the three studied groups on comparing values before and after treatment. In the present study on comparing studied groups, there was no significant differences between the mean score values in the three studied groups before treatment; while after treatment, significant differences were found on comparing either Group I or Group III versus Group II. The mean score value was significantly lower in Group III compared to both Groups I and II. Reduction in dyspeptic symptoms was more likely due to the action of N.sativa oil and omeprazole. There are recent studies which show that aqueous suspension of N.sativa has anti-secretory effects and a protective role for gastric mucosa against injury induced by necrotizing agents and omeprazole is documented to reduce the symptoms in functional dyspepsia as a result of decreasing the gastric acid secretion and increasing the stomach $\mathrm{pH}[12]$
The most commonly recommended triple H.pylori regimen including a Proton Pump Inhibitor (PPI), and a combination of amoxicillin/ metrinodazole and clarithromycin now provide unacceptably low treatment success [26].

In light of emerging resistance, there is a need to look for new remedies effective against H.pylori. It has been shown that essential oils, extracted from plants, are bactericidal against H.pylori without the development of acquired resistance, suggesting that essential oils may have potential as new and safe agents for inclusion in anti H.pylori regimens. Diethyl-ether extract of N.sativa has been reported to inhibit gram-positive and gramnegative bacteria, as well as pathogenic yeast. Recently, crude extracts of N.sativa were reported to have a promising effect on multi-drug resistant organisms, including gram-positive and gramnegative bacteria [12] .

Salem et al., studied the effectiveness of N.sativa oil in eradication of H.pylori in adult patient with non-ulcer dyspepsia compared to the conventional triple therapy and the results encouraged us to study its role in children for the first time.

In the present study, the result showed that triple therapy in Group I significantly eradicate H.pylori in (65\%) of studied children and addition of N.sativa oil to the triple therapy in Group III increased the proportion of eradication to (75\%) of studied children.

In Group II, administration of N.sativa oil combined with PPI alone eradicated H.pylori in $(30 \%)$ of studied children. Salem et al., 2010 in their study on adults compared triple therapy with N.sativa oil. Their results showed that N.sativa oil eradicated H.pylori in infected patients in a proportion (67\%) which i s close to that of standard triple therapy $(82.6 \%)$.

\section{Conclusion:}

Addition of N.sativa to the traditional triple therapy increased the probability of H.pylori eradication more than that achieved through triple therapy alone.

\section{Recommendation:}

- Addition of N.sativa oil in dose of $2 \mathrm{gm} /$ day to triple therapy in management of H.pylori infection in symptomatic children is more effective.

- Further studies using different doses of N.sativa oil is suggested to assess their effects on childhood dyspepsia. 
- Further studies are recommended for assessment of N.sativa oil effect on drug-resistant H.pylori in those receiving many consecutive courses of triple therapy.

\section{References}

1- WATARI J., CHEN N., AMENTA P.S., FUKUI H., OSHIMA T., TOMITA T., et al.: Helicobacter pylori associated chronic gastritis, clinical syndromes, precancerous lesions, and pathogenesis of gastric cancer development. WJG, 20: 5461, 2014.

2- GOLD B.J.: New approach to Helicobacter pylori infection in children. Curr. Gastroenterol. Rep., 3: 235-47, 2001.

3- PORRAS C., NODORA J. and SEXTON R.: Epidemiology of Helicobacter pylori infection in six Latin American countries (SWOG Trial S0701). Cancer Causes Control, 24: 209-15, 2013.

4- ABU-ZEKRY M.A., HASHEM M.E., ALI A.A. and MOHAMED I.S.: Frequency of Helicobacter pylori infection among Egyptian children presenting with gastrointestinal manifestations. J. Egypt Public Health Assoc., 88: 74-8, 2013.

5- SPEE L.A., MADDEROM M.B., PIJPERS M., VAN LEEUWEN Y. and BERGER M.Y.: Association between Helicobacter pylori and gastrointestinal symptoms in children. Pediatrics, 125: e651-69, 2010.

6- DENG Z.H., CHU B., XU Y.Z., ZHANG B. and JIANG L.R.: Influence of Helicobacter pylori infection on ghrelin levels in children. World J. Gastroenterol., 18: 5096-100, 2012.

7- KUSTERS J.G., VAN VLIET A.H. and KUIPERS E.J.: Pathogenesis of Helicobacter pylori infection. Clin. Microbiol. Rev., 19: 449-90, 2006.

8- ROWLAND M., BOURKE B. and DRUMM B.: Helicobacter pylori and peptic ulcer disease. In: Walker WA, Goulet O, Kleinman RE, Sherman PM, Shneider BL, Sanderson IR, editor. Pediatric Gastrointestinal disease. Ontario: BC Decker Inc., p. 491-512, 2004.

9- KHURANA R., FISCHBACH L., CHIBA N., VAN ZANTEN S.V., SHERMAN P.M., GEORGE B.A., et al.: Meta-analysis: Helicobacter pylori eradication treatment efficacy in children. Aliment. Pharmacol. Ther., 25: 52336, 2007.

10- DUCK W.M., SOBEL J., PRUCKLER J.M., SONG Q., SWERDLOW D., FRIEDMAN C., SULKA A., et al.: Antimicrobial resistance incidence and risk factors among Helicobacter pylori-infected persons, United States. Emerg. Infect. Dis., 10: 1088-94, 2004.

11- OHNO T., KITA M., YAMAOKA Y., IMAMURA S., YAMAMOTO T., MITSUFUJI S., et al.: Antimicrobial activity of essential oils against Helicobacter pylori. Helicobacter, 8: 207-15, 2003.

12- SALEM E.M., YAR T., BAMOSA A.O., AL-QUORAIN A., YASAWY M.I., ALSULAIMAN R.M., et al.: Comparative Study of Nigella sativa and Triple Therapy in Eradication of Helicobacter pylori in Patients with NonUlcer Dyspepsia Saudi J. Gastroenterol., 16: 207-14, 2010.

13- SPIROGLOU K., PAROUTOGLOU G., NIKOLAIDES
N., XINIAS I., GIOULEME O., ARSOS G., et al.: Dyspepsia in childhood. Clinical manifestation and management. Ann. Gastroenterol., 17: 173-80, 2004.

14- ABADI A.T. and YAMAOKA Y.: Helicobacter pylori therapy and clinical perspective. J. Glob. Antimicrob. Resist., 14: 111-7, 2018.

15- BAKAL S.N., BERESWILL S. and HEIMESAAT M.M.: Finding novel antibiotic substances from medicinal plantsAntimicrobial properties of Nigella sativa directed against multidrug resistant bacteria. Eur. J. Microbiol. Immunol., 7: 92-8, 2017.

16- HASOSAH M., SATTI M., SHEHZAD A., ALSAHAFI A., SUKKAR G., ALZABEN A., et al.: Prevalence and Risk Factors of Helicobacter pylori Infection in Saudi Children: A Three Year Prospective Controlled Study. Helicobacter, 20: 56-63, 2015.

17-HANAFI M.I. and MOHAMED A.M.: Helicobacter pylori infection: Seroprevalence and predictors among healthy individuals in Al Madinah, Saudi Arabia. J. Egypt Public Health Assoc., 88: 40-5, 2013.

18- GHASEMI-KEBRIA F., GHAEMI E., AZADFAR S. and ROSHANDEL G.: Epidemiology of Helicobacter pylori infection among Iranian Children, 14: 169-72, 2013.

19- CORREA SILVA R.G., MACHADO N.C., CARVALHO M.A. and RODRIGUES M.A.: Helicobacter pylori infection is high in paediatric non ulcer dyspepsia but not associated with specific gastrointestinal symptoms. Acta. Paediatr., 105: 228-31, 2016.

20- RAJ P., THOMPSON J.F. and PAN D.H.: Helicobacter pylori serology testing is a useful diagnostic screening tool for symptomatic inner city children. Acta. Paediatr., 106: 470-7, 2017.

21- WAUTERS L., NIGHTINGALE S., TALLEY N.J., SULAIMAN B. and WALKER M.M.: Functional dyspepsia is associated with duodenal eosinophilia in an Australian paediatric cohort Aliment. Pharmacol. Ther., 45: 135864, 2017.

22- ÇıNAR A., SADıÇ M. and iKBAL AT1LGAN H.: Prevalence of Helicobacter Pylori Infection in School and PreSchool Aged Children with C-14 Urea Breath Test and the Association with Familial and Environmental Factors. Mol. Imaging Radionucl. Ther., 24: 66-70, 2015.

23- OZBEY G. and HANAFIAH A.: Epidemiology, Diagnosis, and Risk Factors of Helicobacter pylori Infection in Children. Euroasian J. Hepatogastroenterol., 7: 34-9, 2017.

24- KONNO M., FUJII N., YOKOTA S., SATO K., TAKAHASHI M., SATO K., et al.: Five-year follow-up study of mother-to-child transmission of Helicobacter pylori infection detected by a random amplified polymorphic DNA fingerprinting method. J. Clin. Micr. Obiol., 43: 2246-50, 2005.

25- JONES M.P., VAN OUDENHOVE L., KOLOSKI N., TACK J. and TALLEY N.J.: Early life factors initiate a 'vicious circle' of affective and gastrointestinal symptoms: A longitudinal study. United European Gastroenterol. J., 1: 394-402, 2013.

26- HUANG Y. and ZHAN X.: Sequential therapy is superior to triple therapy for Helicobacter pylori infection in children: A meta-analysis. Indian J. Pediatr., 83: 307-15, 2016. 


\section{دراسة دور إستخدام زيت حبة البركة فى القضاء على العدوى الإي

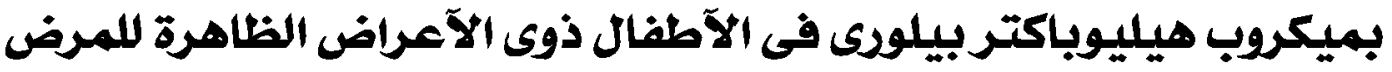

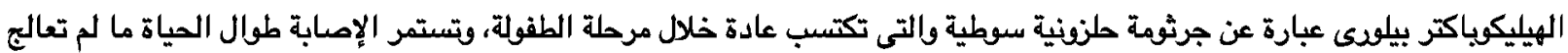

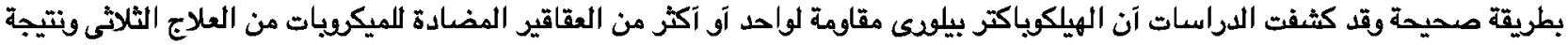

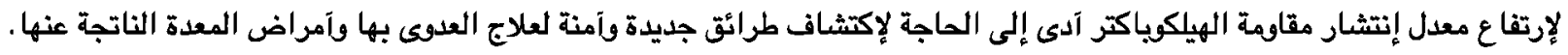
الهدف من البحث: هو دراسة الدو المحتمل للزيت حبة البركة فى القضاء على عدوى الهيليكوباكتر بيلوىى فى الآطفال ذوى الآعراض الظطاهرة المرض.

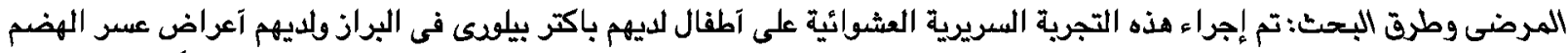

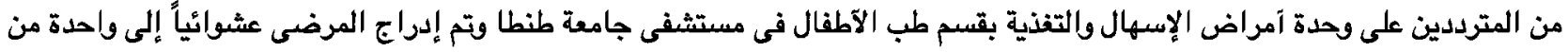

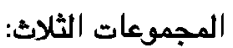

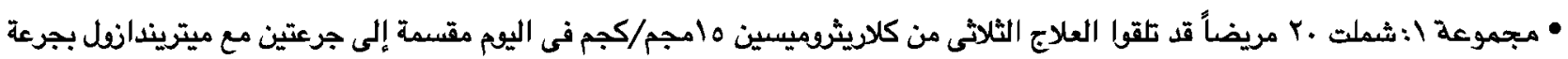

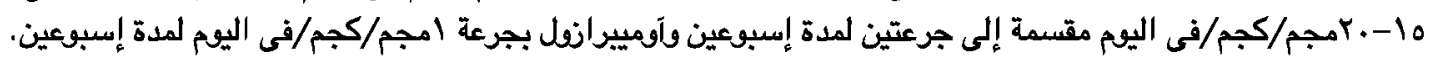

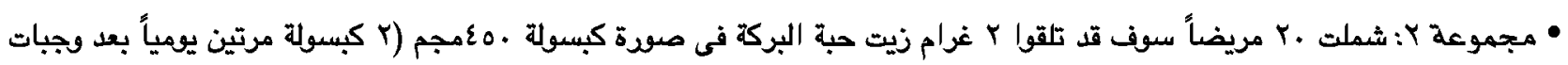
الطعام) مع آومييرانفل امجم/كجم في اليقم لمدة إسبوعين.

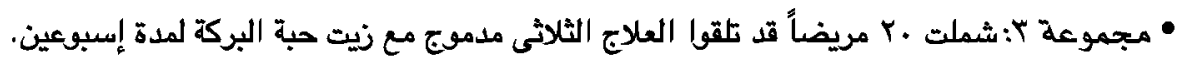

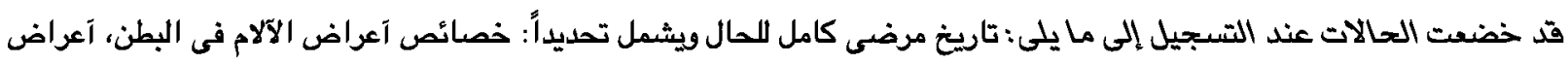

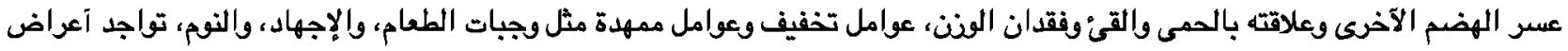

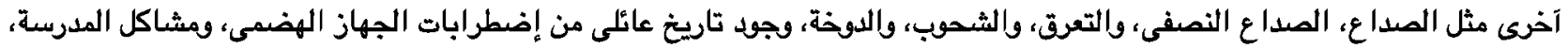

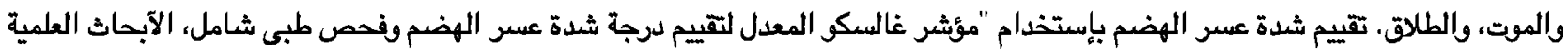

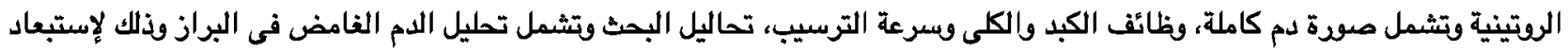

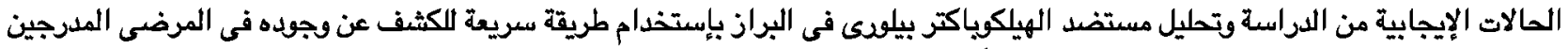

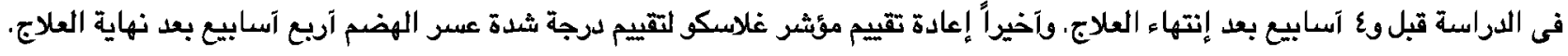

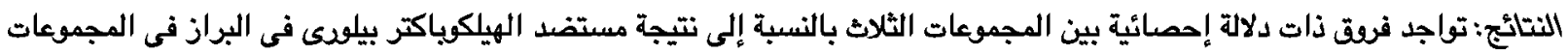

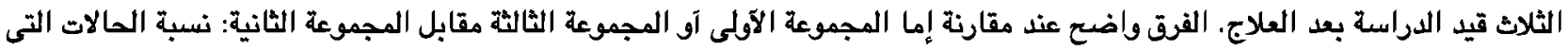

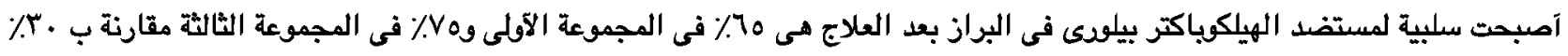
فقط من المرضى فى المجموعة الثانية. الإستتاج: إضـافة زيت حبة البركة إلى العلاج الثلاثى المعتاد يزيد من قوة تآثير العلاج فى القضاء على عدوى الهيلكوباكتر عن ذلك الناتج عن إعطاء العلاج الثالثى بمفرده.

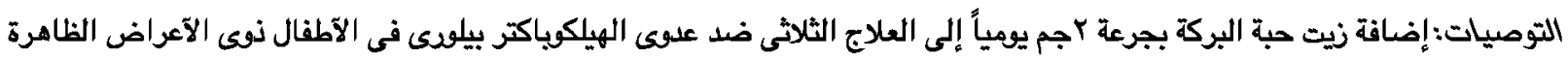

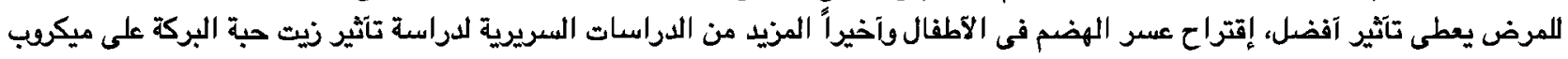

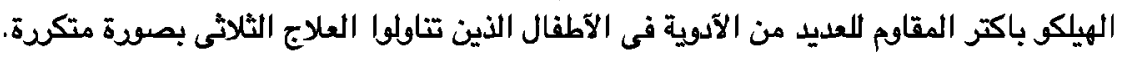

